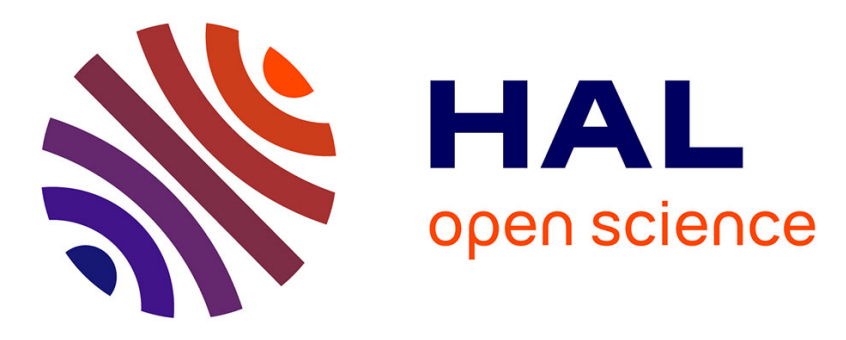

\title{
Johannes Schneider: Eine buddhistische Kritik der indischen Götter. Śạ̣karasvāmins Devātiśayastotra mit Prajñāvarmans Kommentar. Nach dem tibetischen Tanjur herausgegeben und übersetzt.
}

Hugo David

\section{To cite this version:}

Hugo David. Johannes Schneider: Eine buddhistische Kritik der indischen Götter. Śaṃkarasvāmins Devātiśayastotra mit Prajñāvarmans Kommentar. Nach dem tibetischen Tanjur herausgegeben und übersetzt.. Bulletin of the School of Oriental and African Studies, 2016, pp.210-212. 10.1017/S0041977X15001317 . halshs-02417433

\section{HAL Id: halshs-02417433 \\ https://shs.hal.science/halshs-02417433}

Submitted on 3 Jan 2020

HAL is a multi-disciplinary open access archive for the deposit and dissemination of scientific research documents, whether they are published or not. The documents may come from teaching and research institutions in France or abroad, or from public or private research centers.
L'archive ouverte pluridisciplinaire HAL, est destinée au dépôt et à la diffusion de documents scientifiques de niveau recherche, publiés ou non, émanant des établissements d'enseignement et de recherche français ou étrangers, des laboratoires publics ou privés. 
Land was becoming recognizably Buddhist. (He suggests it was originally influenced by Central Asian monotheism). Later "Aśoka" inscriptions either affect to be by Aśoka but could not be, or possibly there is another Aśoka, but some are definitely spurious. Beckwith urges Indologists to acknowledge the blatant forgeries among the inscriptions and sort this out once and for all.

The Lumbini story is, as Bareau has shown, a late fabrication. The Four Noble Truths and the Eightfold Noble Path are later formulations, from "Normative" Buddhism. Unreformed Mazdaism was in competition with reformed Zoroastrianism. Some Zoroastrian and Mazdean doctrines were adopted directly by Brahmanism, others later from Normative Buddhism. At first Buddhism was very opposed to it. But it seems in popular strands to have adopted good and bad karma and rebirth.

Beckwith argues that the Greek monoglot theory deserves to be put to rest, in particular the Inspector Clouseau-like invasion of these lands by Alexander. The theory that everything came from Greece, which he rather unfairly attributes to McEvilley, is not valid either. The ancient sources say philosophia's origin was the barbaroi, especially the Central Asians.

Beckwith discusses the correct meaning of adoxastous. It is not free of "opinions" but "beliefs". The result, what is left (periesesthai), is ataraxia, like a shadow. What Pyrrho means is the circularity of induction and deduction, and Beckwith argues that it makes sense as it is. One of the strengths of the book is its interpretation that the implications of Pyrrho's arguments are logical. His discussion of how this influenced Hume, and what this might mean for our ideas of perfection and beauty, contributes to our understanding of Pyrrhonism to a degree, but it feels like a different book.

One would have to commend the author's audacity. This revision of the history of Early Buddhism is likely to offend those who, as he puts it, have to guard their views with imprecations in ancient tongues.

Nevertheless, the book offers a new and refreshing approach. It repeatedly calls for more work in various fields, and it should be hoped that scholars do not shy away from taking up the many challenges it raises.

Matthew Neale

University of Cambridge

JOHANNES SCHNEIDER:

Eine buddhistische Kritik der indischen Götter. Śamkarasvāmins

Devātiśayastotra mit Prajñāvarmans Kommentar. Nach dem tibetischen

Tanjur herausgegeben und übersetzt.

(Wiener Studien zur Tibetologie und Buddhismuskunde 81.) x, 195 pp.

Vienna: Arbeitskreis für tibetische und buddhistische Studien der

Universität Wien, 2014. €18. ISBN 9783902501196.

doi:10.1017/S0041977X15001317

The present monograph by Johannes Schneider is an in-depth philological study of two Sanskrit texts of Buddhist apologetics, Samkarasvāmin's Devātiśayastotra ("Praise of [the Buddha's] superiority over the gods") and its commentary, the Devātiśayastotrațīka (DASṬ) by Prajñāvarman (eighth-ninth c.?). While only the first has been preserved in its original language, both works were translated at a 
comparatively early date into Tibetan and are now found in the first volume of the Tanjur. Schneider provides us here with a first critical edition and German translation of the Tibetan versions of the DAS (pp. 37-58) and the DAST (pp. 59-160). These are preceded by a substantial introduction (pp. 1-36) dealing with the establishment of the Tibetan text, the authors and the translators of the works, and their contents. This is followed by a new edition of the Sanskrit text of the DAS (pp. 1637), which improves on the earlier versions of L. Norbu Shastri and M. Hahn, as well as an exhaustive set of indices (pp. 169-82) and a bibliography (pp. 183-95).

This study is the last in a series devoted to the works of Samkarasvāmin and his brother Udbhatasiddhasvāmin, who both lived in Eastern India (Magadha, following an indication by Tāranātha) possibly in the first centuries of the first millennium CE (a detailed discussion of Śamkarasvāmin's dates is found on pp. 15-8). In two earlier publications, Schneider dealt with Udbhațasiddhasvāmin's two hymns: the Viśesastava, also commented upon by Prajñāvarman, and the Sarvajñamaheśvarastotra (see J. Schneider, Der Lobpreis der Vorzüglichkeit des Buddha. Udbhatasiddhasvāmins Viśeșastava mit Prajñāvarmans Kommentar. Nach dem tibetischen Tanjur herausgegeben und übersetzt. Indica et Tibetica 23. Bonn: Indica-et-Tibetica-Verlag, 1993; J. Schneider, "Der Buddha als der wahre Śiva. Udbhațasiddhasvāmins Sarvajñamaheśvarastotra", Berliner indologische Studien 8, 1995, 153-87). The present book, devoted to Śạkarasvāmin's work and its commentary, thereby brings to completion the study of this small but important corpus of early Buddhist polemical tracts, including their only known Indian gloss.

Śamkarasvāmin's text (21 stanzas composed in various Sanskrit meters) belongs, as do Udbhatasiddhasvāmin's Stava and Stotra, to the genre of Buddhist religious apologetics. It consists for the most part of a demonstration of the moral superiority of the Buddha over Hindu gods (Śiva, Brahmā, Viṣnu, Skanda, Ganeśa, etc.) and religious teachers (Kan̄āda and Kapila, the founders of Vaiśeșika and Sāmkhya respectively, are mentioned in vv. 11 and 17). Although the title of the work makes it a "song of praise" (stotra) in honour of the Buddha, this aspect is by no means prominent in the text, which is written in the third person (unlike other stotras of the same period, like Udbhața's Viśeșastava or Mātrceța's Śatapañcāśatka and Catuhśataka) and better read as an attempt to justify Buddhist faith against Hindu beliefs. The possibility that Śamkarasvāmin and his brother converted from Śaivism to Buddhism, to which both Prajñāvarman and Tāranātha bear testimony, would explain, according to Schneider, this predominantly polemical nature of their works, as well as their acquaintance with Hindu epics and Purānas. Śamkarasvāmin's repeated protest of impartiality and good faith (see in particular vv. 10,11 and 17) also makes it quite plausible that the hymn was used in a context of Buddhist proselytism. Whatever the case may be, Śạkarasvāmin's insistence on showing the Buddha's superiority from a strictly moral point of view (rather than through the intrinsic absurdity of Hindu dogmas) makes the DAS quite a unique work; it contrasts sharply with the overwhelmingly doctrinal character of religious polemics in later philosophical works. It is interesting to note, nevertheless, some similarity with certain passages of Bhavya/Bhā(va)viveka's Madhyamakahrdayakārikās (see for instance vv. 9.63-73 and 9.108-111), where the learned sixth-century Buddhist scholar also uses the alleged moral depravation in speech and behaviour of the Hindu gods as an argument against their trustworthiness, in a tone that is no less harsh than that of the old polemicists.

More than just a word-for-word gloss of Śamkarasvāmin's text, Prajñāvarman's commentary offers the reader a precious glimpse into the intellectual and religious life of eighth- and ninth-century Tibet. Being himself associated with the translation into Tibetan of almost 80 Sanskrit works (77 according to the catalogue of the Tibetan canon), the learned Bengali pandit may have written his commentary - 
according to Schneider's hypothesis (p. 26) - for the benefit of the Tibetan scholars he was working with, and perhaps directly in Tibet. This indeed would explain the systematic manner in which Indian myths are narrated in the DAST, as well as the very purpose of writing a commentary on a set of relatively simple Sanskrit verses. If much of the material provided is admittedly familiar, the text also contains a wealth of little-known stories, making it as instructive to us perhaps as it was to his Tibetan contemporaries. It is in Prajñāvarman's commentary, for instance, that we find the first occurrence of the myth of the Indian origin of the Tibetan people from the defeated army of king Rupati. Readers interested in the early history of Indian philosophical systems will also appreciate the colourful account of how Akṣapāda founded Mīmāmsāa [sic] through a favour of Śiva for his careful watch over Umā and his withstanding her seductive moves by staring at his feet (whence the name aksapāda, Tib. Rkang mig!).

These, of course, are only a few examples of what can be gleaned from these very rich and little-known Buddhist works, of which Schneider provides us here a masterful study. Let us finally note that the very readable German translation and insightful comments will satisfy both the specialist of Indian Buddhism and the general reader. With this work, Schneider aptly pursues the task of early Tibetan translators: leading the path to Indian Buddhist thought for those who, being remote in place or time, have only fragmentary knowledge of the world in which it arose.

Hugo David
École française d'Extrême-Orient

THERESIA HOFER (ed.):

Bodies in Balance - The Art of Tibetan Medicine.

360 pp. New York: Rubin Museum of Art, in association with University of Washington Press, 2014. \$74.95. ISBN 9780295993591. doi:10.1017/S0041977X15001329

This beautifully designed and richly illustrated catalogue has been produced for an extraordinary exhibition on the art of Tibetan medicine staged at the Rubin Museum, New York, in 2014. Editor, curator and social anthropologist Theresia Hofer has contributed to and compiled a compelling multidisciplinary series of chapters by international experts. The book explores the convergent spaces of Tibetan medicine, also known as Sowa Rigpa or the "science of healing", as a knowledge system with different forms of practice, including its complex interaction with Buddhism. Due to the rich illustrations used as technical supports in this medical knowledge system, the book will also appeal visually to both the wider public and scholars of Asian medicine. The first part of the work introduces the reader to theoretical principles and practices of Tibetan medicine, while the second focuses on medicine, religion and historical developments. We learn not only how Tibetan medicine has developed over the past 1,000 years in Tibet, the Himalayas and regions of Central Asia and southern Siberia, but also of its ongoing, recent transformation into an increasingly globalized Asian medical practice. The catalogue presents relevant artefacts, including medical paintings, Buddha statues and surgical objects from all of these regions. Overall, the volume admirably represents both the unity and diversity of Sowa Rigpa's "harmonious polyphony", contextualized by recent and wellgrounded ethnographic and historical research. 